\title{
INTER-ORGANIZATIONAL COST MANAGEMENT AND OPEN BOOK ACCOUNTING: A REVIEW
}

\author{
Bakil DhaifAllah, Sofiah Md Auzair, Ruhanita Maelah \& \\ Md Daud Ismail
}

\begin{abstract}
This paper aims to review the recent literature on inter-organizational cost management (IOCM) and open book accounting (OBA) practices, and their relationship with cost reduction. Based on the method used, a comprehensive review of relevant literature on this topic between 1992 and 2016, was sourced, collected, and summarized. Subsequently, two major findings were drawn. First, studies in the US, UK, and Japan dominated research on the area of IOCM and OBA, but, in recent years, more European and other countries are becoming involved. Second, the reviewed studies show that IOCM and OBA improve inter-organizational relationships, particularly, when the partners develop relational safeguards to prevent opportunism. However, the conclusions from the conceptual and case studies on the role of IOCM and OBA to reduce costs in the supplier-buyer relationships were contradictory. This paper furthers the understanding of the contributions introduced in prior studies on IOCM and OBA, and helps to identify some future research directions.
\end{abstract}

Keywords: Inter-Organizational Cost Management, Open Book Accounting JEL Classification: M41, M49

\section{Introduction}

Inter-organizational relationships are created, maintained and improved to achieve firms' goals that might be difficult to accomplish by individual firms separately (Cheng, 2011). In fact, today's complicated and uncertain market leads firms to focus on their core competencies, as a way to ensure their competitiveness and add unique value to customers (Prahalad \& Hamel, 2006). Consequently, firms are increasingly outsourcing non-core activities and functions to external vendors and focusing on their core competencies (Belcourt, 2006; Ghodeswar \& Vaidyanathan,

Corresponding author: Bakil DhaifAllah is a lecturer at the Department of Accounting, Faculty of Administrative Sciences, Thamar University, Yemen. He is currently pursuing his $\mathrm{PhD}$ at the School of Accounting, Faculty of Economics and Management, Universiti Kebangsaan Malaysia, 43600 Bangi, Selangor, Malaysia. Email: bakil@siswa.ukm.edu.my.

Sofiah Md Auzair is an Associate Professor at the School of Accounting, Faculty of Economics and Management, Universiti Kebangsaan Malaysia, 43600 Bangi, Selangor, Malaysia. Email: sofiah@ukm.edu.my.

Ruhanita Maelah is an Associate Professor at the School of Accounting, Faculty of Economics and Management, Universiti Kebangsaan Malaysia, 43600 Bangi, Selangor, Malaysia. Email: ruhanita@ukm.edu.my.

Md Daud Ismail is an Associate Professor at the School of Management, Faculty of Economics and Management, Universiti Kebangsaan Malaysia, 43600 Bangi, Selangor, Malaysia. Email: mddaud@ukm.edu.my. 
2008; Jiang, Belohlav, \& Young, 2007; Mahmoodzadeh, Jalalinia, \& Nekui Yazdi, 2009). As a result of the outsourcing strategy, firms' success depends more on the efficiency and effectiveness of their supply networks (Cooper \& Slagmulder, 1999).

However, many of these relationships fail to achieve their expected results due to coordination problems and misalignment of actions (Dong, Ju, \& Fang, 2016; Dyer \& Hatch, 2006; Yan \& Dooley, 2013). These problems arise due to the cognitive limitations of partners that deny them comprehensive knowledge of how others will behave in situations of interdependence, and how they are interdependent with others (Gulati, Lawrence, \& Puranam, 2005). In other words, coordination problems mainly result from the lack of shared and accurate knowledge about decision rules that the other partners are likely to use (Hanf \& Dautzenberg, 2007). Tsamenyi et al. (2010) stated that approximately half to twothirds of inter-organizational relationships do not achieve their intended goals. This indicates that inter-organizational relationships and outsourcing strategies imply the problem of information asymmetries among partners. This issue refers to the difference between the information possessed by the suppliers and the buyers (Ba \& Pavlou, 2002). The information asymmetry between partners increases the transaction costs of market exchanges (Williamson, 1985). This is because suppliers usually have more information about their products than their customers; hence, customers incur search and monitoring costs to identify suppliers that have characteristics that are desirable but costly to observe (Montiel, Husted, \& Christmann, 2012). Asymmetries in information create problems in monitoring performance, which can increase transaction risks (Clemons \& Row, 1992) and lead to greater operational inefficiencies and coordination costs (Patnayakuni, Rai, \& Seth, 2006). Furthermore, information asymmetries increase costs, such as for comparing products, negotiating prices, drafting agreements to ensure that suppliers possess the unobservable characteristics that they claim to have, and the monitoring costs of meeting the contractual terms (Cowen \& Parker, 1997; Li, Humphreys, Yeung, \& Cheng, 2012; Milgrom \& Roberts, 1992; Yeung, 2008). Arguably, these costs are viewed as crucial factors that influence the nature of inter-organizational relationships (Bunduchi, 2005) and negatively affect the supplier performance, buyer satisfaction and relationship's overall performance (Cai, Yang, \& Hu, 2010; Chalos \& O'Connor, 2005). Therefore, issues concerning the costs of coordination, information asymmetries, and transaction costs have led firms in interorganizational relationships to seek efficient practices to reduce the information asymmetries and manage the costs that span the firm's boundaries (Cooper \& Slagmulder, 2004). The issue of cost management between firms leads to the introduction of inter-organizational accounting practices (Håkansson \& Lind, 2004, 2006).

The area of inter-organizational accounting practices has attracted considerable attention since the 1990s. This attention has been particularly documented in several conceptual and empirical studies within many different industries around the world. These industries include automotive, mechanical engineering, plastic, retail, service, computer, telecommunications, information technology service, electrical installation, industrial maintenance and the public sector (e.g. Agndal and Nilsson, 
2008, 2010; Alenius, Lind, and Strömsten, 2015; Carr and Ng, 1995; Cooper and Slagmulder, 2004; Dekker and Smidt, 2003; Frances and Garnsey, 1996; Gietzmann, 1996; Håkansson and Lind, 2004; Hoffjan and Kruse, 2006; Jones, 1999; Möller, Windolph, and Isbruch, 2011; Mouritsen and Thrane, 2006; Munday, 1992; Romano and Formentini, 2012; Roodhooft and Warlop, 1999; Seal, Berry, and Cullen, 2004; Seal, Cullen, Dunlop, Berry, and Ahmed, 1999; Van der MeerKooistra and Vosselman, 2000; Widener and Selto, 1999; Windolph and Möller, 2012). A significant result of these studies was identifying the practices and instruments in inter-organizational accounting. This includes main practices, such as inter-organizational cost management (IOCM), open book accounting (OBA), value-chain accounting, integrated information systems and the total cost of ownership (Håkansson and Lind, 2006).

With the emphasis on the long-term relationship, IOCM and OBA have been recognized in previous studies as competitive tools to ensure inter-organizational network competitiveness and efficiency (Cooper and Slagmulder, 1999; Kajüter and Kulmala, 2005; Kulmala, Paranko, and Uusi-Rauva, 2002; Möller et al., 2011; Slagmulder, 2002; Windolph and Möller, 2012). Therefore, researchers have begun to investigate these practices to identify the success factors and illustrate their implications (e.g. Agndal and Nilsson, 2009, 2010; Alenius et al., 2015; Caglio and Ditillo, 2012a, 2012b; Fayard, Lee, Leitch, and Kettinger, 2012; Kajüter and Kulmala, 2005; Kulmala, Kajüter, and Valkokari, 2007; Möller et al., 2011; Romano and Formentini, 2012; Singh, Seshadri, Kumra, Agndal, and Nilsson, 2012; Sohn, Shin, and Park, 2014; Uddin, 2013; Uddin and Hassan, 2011; Windolph and Möller, 2012).

According to Cooper and Slagmulder (2004), IOCM and OBA were proposed to reduce the information asymmetry that exists between the supplier and the buyer regarding the specifications of the outsourced product established by the buyer and the resulting costs of the supplier. Therefore, when the partners identify any information asymmetries as the cause of the costs overrun, IOCM and OBA can be implemented to find lower cost solutions. These practices, when compared to traditional cost management, are expected to result in additional opportunities for cost reduction. These opportunities arise through the collaborative efforts of the partners in the relationship. In order to reveal such opportunities, coordination activities and disclosure of product cost structures are considered to be critical (Cooper and Slagmulder, 1999; Mouritsen, Hansen, and Hansen, 2001). Therefore, IOCM and OBA are required to operate in an integrated manner to reduce the costs through supplier-buyer coordinated actions (Cooper and Slagmulder, 1999). The main objective of IOCM is to determine and realize lower-cost solutions by means of inter-organizational coordinated actions (Cooper and Slagmulder, 1999). OBA, which relates to management accounting information disclosure, refers to the data and information that are shared with the partner in the inter-organizational network (Caglio and Ditillo, 2012b). This type of disclosure is a prerequisite for implementing IOCM (Ellram, 1996). Thus, IOCM and OBA may help to identify cost reduction opportunities within networks and supplier-buyer relationships (Cooper and Slagmulder, 1999; Kajüter and Kulmala, 2005; Ramos, 2004). 
According to Håkansson and Lind (2006), inter-organizational accounting practices are mainly directed at linking the resources and internal activities of one firm to those belonging to the suppliers and customers of that firm. Therefore, they are adopted for controlling inter-organizational transactions and improving interorganizational efficiency and effectiveness.

Table 1.1: Distribution of IOCM and OBA Studies Based on Region.

\begin{tabular}{|c|c|c|c|}
\hline Authors & $\begin{array}{l}\text { Research } \\
\text { Approach }\end{array}$ & Region & Study Focus \\
\hline Munday (1992) & Quantitative & UK & Accounting cost data disclosure \\
\hline Cooper and Yoshikawa (1994) & Qualitative & Japan & IOCM \\
\hline Carr and $\mathrm{Ng}(1995)$ & Qualitative & UK & Total cost control \\
\hline Seal et al. (1999) & Qualitative & UK & $\begin{array}{l}\text { Management accounting in supply } \\
\text { chain }\end{array}$ \\
\hline Mouritsen et al. (2001) & Qualitative & Denmark & Target costing and OBA \\
\hline McIvor (2001) & Quantitative & UK & $\begin{array}{l}\text { Joint buyer-supplier cost reduction and } \\
\text { open book costing }\end{array}$ \\
\hline Dekker (2003) & Qualitative & UK & $\begin{array}{l}\text { Value chain analysis and integrated } \\
\text { cost information across the supply } \\
\text { chain }\end{array}$ \\
\hline Cooper and Slagmulder (2004) & Qualitative & Japan & IOCM \\
\hline Kulmala (2004) & Qualitative & Finland & $\begin{array}{l}\text { Cost management in supplier-buyer } \\
\text { relationship }\end{array}$ \\
\hline Kajüter and Kulmala (2005) & Qualitative & $\begin{array}{l}\text { Germany and } \\
\text { Finland }\end{array}$ & OBA \\
\hline Kulmala et al. (2007) & Qualitative & Finland & IOCM \\
\hline Wagner (2008) & Quantitative & Switzerland & $\begin{array}{l}\text { Cost management for supply chain } \\
\text { management }\end{array}$ \\
\hline Agndal and Nilsson (2009) & Qualitative & Sweden & IOCM \\
\hline Agndal and Nilsson (2010) & Qualitative & Sweden & OBA \\
\hline Yigitbasioglu (2010) & Quantitative & $\begin{array}{l}\text { Finland and } \\
\text { Sweden }\end{array}$ & Information sharing with key suppliers \\
\hline Möller et al. (2011) & Quantitative & Germany & IOCM and OBA \\
\hline Caglio and Ditillo (2012a) & Qualitative & Italy & Interdependence and OBA \\
\hline Caglio and Ditillo (2012b) & Qualitative & Italy & OBA \\
\hline Fayard et al. (2012) & Quantitative & US & IOCM \\
\hline Windolph and Möller (2012) & Quantitative & Germany & IOCM and OBA \\
\hline Singh et al. (2012) & Qualitative & India & OBA \\
\hline Alenius et al. (2015) & Qualitative & Sweden & OBA \\
\hline Farias and Gasparetto (2016) & Qualitative & Brazil & IOCM \\
\hline
\end{tabular}

Since the 1990s, researchers have begun to focus attention on IOCM and OBA. Up until now, considerable effort has been spent on understanding the concepts, implementations, implications, and challenges of IOCM and OBA in reducing costs. Table 1.1 shows the geographical area and focus of previous empirical studies. For almost two decades, the studies concentrated on IOCM and OBA in advanced countries. Furthermore, there has been more focus on qualitative methods to understand the practices, probably to capture the in-depth issues surrounding the cost management techniques. Nevertheless, a rigorous and objective review of the literature is required to draw meaningful conclusions and directions for future research on these issues. In particular, we are interested in understanding the contributions of IOCM, OBA, and their relationship with cost reduction in inter-organizational relationships. Thus, IOCM and OBA studies, including conceptual and empirical studies, were comprehensively reviewed.

This research began with the identification of search terms. Specific keywords were used to search for relevant papers regarding IOCM and OBA. 
The search strategy for the review was directed towards finding published papers in archival journals from the contents of databases, mainly including Elsevier, Emerald insight, Springer, and Taylor and Francis. The search terms used were inter-organizational cost management and open book accounting. From the resulting papers, the selection process was based on reading the entire paper to decide on its relevance to the two constructs.

The remainder of this paper is organized as follows. The next section reviews studies on IOCM and OBA, which have been classified according to the methodological approaches adopted. Lastly, a brief discussion on whether to study IOCM and OBA as one or different practices is provided. The final section provides some concluding comments.

\section{IOCM Studies}

In this section, this paper reviews IOCM studies based on the research methodology followed to allow consideration of the way in which IOCM has been addressed. This includes a brief sketch to illustrate the concept, practices, implications, and challenges. This is followed by a review of related case-based and survey-based studies.

\subsection{Brief Sketch}

This section provides a review of the development of IOCM and its practices identified in prior research. Following this, the relationship between IOCM and cost reduction is discussed.

IOCM has been developed to tackle the issue of information asymmetry between suppliers and buyers in inter-organizational relationships and networks, and to identify lower cost solutions by changing the specifications of the outsourced item or the end product (Cooper and Slagmulder, 2004). The origin of IOCM can be traced back to the work of Porter (1985) who argued that linkages between suppliers and buyers lead to opportunities for cost reduction through two mechanisms: coordination and optimization. Following that, Shank (1989) suggested that managing costs effectively requires a broad focus that is external to the firm's boundaries. The study indicated that strategic cost management emerges from three underlying themes, namely, value chain analysis, strategic position analysis, and cost driver analysis. Building on these studies, IOCM has emerged and been defined as a structured approach to coordinating the activities of firms in a supplier network so that the total costs in the network are reduced (Cooper and Slagmulder, 1999).

Despite the attention IOCM has acquired in the cost accounting literature, Seuring (2002) stated that no conceptual framework for a systematic assessment of costs in supply chains had been presented. Seuring attempted to develop a framework for supply chain costing using three steps involving the productrelationship-matrix, the three cost levels (direct, activity-based and transactions cost), and the integration of the product, relationship and costs. This study argued that IOCM describes the product and the relationship dimensions, but does not 
integrate them or take the cost dimension into account. Similarly, Chen (2011) mentioned that only a small number of studies addressed the IOCM practices and implementation in inter-organizational networks. The study, therefore, attempted to develop a framework to understand IOCM based on accounting data disclosure (nature, use, and conditions), which is recognized as a critical foundation for IOCM implementation. Uddin and Hassan (2011) proposed an approach "inter-firm cost management theory" that dealt with inter-organizational relationships. This approach combined dyadic and network relationships with formal and informal communications and focused on cost management across the firm's boundaries in collaborative relationships. The study concluded that more investigation on interfirm cost management is required.

Although several conceptual and empirical studies have addressed IOCM, consistent practices of IOCM have not yet emerged (Möller et al., 2011; Windolph and Möller, 2012). The review indicates a variation in the practices of IOCM among inter-organizational relationships. Cooper and Slagmulder (2004), for example, identified three clusters of IOCM practices adopted by selected firms including 1) functionality price quality trade-offs, inter-organizational cost investigations, and concurrent cost management, 2) functionality price quality trade-offs and inter-organizational cost investigations, and 3) functionality price quality trade-offs. In addition, Kajüter and Kulmala (2005) found that a broad range of practices is applied during the development and manufacturing stages to identify potential cost reduction solutions (e.g. target costing, value engineering and cost tables). Similarly, a variation in IOCM practices is recognized by Agndal and Nilsson (2009). In their study, generally, three practices were identified as frequently presented IOCM practices including 1) target costing, 2) trade-off techniques (such as inter-organizational cost investigations and concurrent cost management) and continuous improvement, and 3) techniques and philosophies related to suppliers' costs, such as OBA and cost tables. The study identified some activities in the supplier-buyer's exchange process where IOCM is relevant. It was revealed that the remarkable and profound collaboration around IOCM practices with the great joint use of suppliers' management accounting regularly occurs in earlier activities in the exchange process. Activities including supplier selection, joint product design, and joint manufacturing process development were also identified in the earlier stages. These activities are recognized as offering important opportunities for cost reduction of the final product. In a more recent case study, Sohn et al. (2014) examined the process of IOCM implementation between the buyer and the suppliers in Korea. The study showed the implementation of IOCM including target costing, functionality price quality trade-offs technique and techniques relating to suppliers' costs. The study illustrated how the buyer established an IOCM infrastructure in order to improve IOCM effectiveness. Based on these reviews, in the main, IOCM can be categorized into four practices: 1) target costing, 2) functionality price quality trade-offs, 3) inter-organizational cost investigation, and 4) concurrent cost management. Table 2 provides a summary of the IOCM practices indicated in prior research. 
Table 2.1: IOCM General Practices Based on Previous Studies

\begin{tabular}{|c|c|}
\hline Authors & IOCM Practices \\
\hline $\begin{array}{l}\text { Cooper and } \\
\text { Yoshikawa (1994) }\end{array}$ & $\begin{array}{l}\text { 1) Target costing systems, 2) Functionality price quality trade-offs, 3) Minimum cost } \\
\text { investigations }\end{array}$ \\
\hline Slagmulder (2002) & $\begin{array}{l}\text { 1) Target costing, 2) Functionality price quality trade-offs, 3) Inter-organizational cost } \\
\text { investigation, 4) Concurrent cost management }\end{array}$ \\
\hline Kajiiter (2002) & $\begin{array}{l}\text { 1) Target costing and chained target costing, 2) Functionality price quality trade-offs, 3) Inter- } \\
\text { organizational cost investigation, 4) Concurrent cost management, 5) Kaizen costing, 6) } \\
\text { Value analysis, 7) Value engineering }\end{array}$ \\
\hline Cooper and & 1) Functionality price quality trade-offs, 2) Inter-organizational cost investigation, 3) \\
\hline (2004) & Concurrent cost management \\
\hline $\begin{array}{l}\text { Agndal and Nilsson } \\
\text { (2009) }\end{array}$ & $\begin{array}{l}\text { 1) Target costing, 2) Trade-off techniques and continuous improvement 3) Inter- } \\
\text { organizational cost investigations, 4) concurrent cost management, 5) Value engineering, 6) } \\
\text { value analysis and "kaizen" or "continuous improvements," 7) Philosophies and techniques } \\
\text { related to suppliers' costs , 8) Costs tables, 9) OBA }\end{array}$ \\
\hline Möller et al. (2011) & $\begin{array}{l}\text { 1) Target costing, 2) Functionality price quality trade-offs, 3) Inter-organizational cost } \\
\text { investigation, 4) Concurrent cost management }\end{array}$ \\
\hline Fayard et al. (2012) & $\begin{array}{l}\text { 1) Inter-organizational applications of activity-based costing, 2) Target costing, 3) Kaizen } \\
\text { costing, 4) OBA }\end{array}$ \\
\hline $\begin{array}{l}\text { Windolph and Möller } \\
\text { (2012) }\end{array}$ & $\begin{array}{l}\text { 1) Target costing, 2) Functionality price quality trade-offs, 3) Inter-organizational cost } \\
\text { investigation, 4) Concurrent cost management }\end{array}$ \\
\hline
\end{tabular}

\subsection{IOCM and Cost Reduction}

The benefits of an inter-organizational costing approach were reviewed by Bastl, Grubic, Templar, Harrison, and Fan (2010). It is argued that the successful implementation of inter-organizational costing results in improved business relationships, increased visibility of product profitability, transferal of competitive pressure upstream of a supply chain, increased knowledge of firm's process-related cost and business process, a better understanding of the real cost of doing business, and improved decision-making.

Generally, IOCM is recognized as a cost reduction programme in interorganizational relationships. It is argued that IOCM assists firms to reduce costs in two ways: firstly, it may help to identify ways to make the interface between firms in networks more effective and efficient. Secondly, it can help a firm and its buyers and suppliers to find ways to lower the manufacturing costs of the product (Kulmala et al., 2002). According to Cooper and Slagmulder (2004), the outsourcing of items introduces the issue of information asymmetry between the partners in the make orbuy decision. This information asymmetry can cause the buyer to establish product specifications that unnecessarily increase the costs incurred by the supplier. In order to lower the costs associated with this information asymmetry, teams from both sides may meet during the product development process and identify opportunities to alter the buyer's specifications in ways that reduce the overall costs.

In a conceptual study on proactive cost management in supply chains, Kajiiter (2002) suggested that IOCM requires close collaboration between suppliers and buyers to achieve cost reduction. Therefore, this practice involves the relationship and product as the main dimensions to establish the environment for joint cost management efforts and improve inter-organizational costs during the product life cycle. In the same way, Slagmulder (2002) indicated that IOCM is a development programme that enables firms to jointly reduce costs during the product design and manufacturing stages. To achieve its benefits, it is emphasized that IOCM should start as a cultural process with the establishment of the appropriate supplier-buyer 
relationships. This is because IOCM is mainly based on the degree of cooperation, stability and mutual benefit.

Arguably, supply chain management aims at reducing costs that require specific concepts of cost management, such as supply chain costing, proactive cost management, lean management accounting and IOCM (Surowiec, 2013). Surowiec argued that the implementation of IOCM requires firms to determine the specific goals of cost reduction with regard to suppliers. Furthermore, firms need to collaborate with suppliers and customers to find ways to lower costs taking into account the suppliers' profitability when negotiating the price and in ensuring effective collaboration with suppliers and customers.

In a nutshell, IOCM practices can help partners to either jointly find ways for the suppliers to manufacture the components at a reduced cost, or move activities and functions between them so that these activities and functions can be performed more efficiently at a reduced cost (Slagmulder, 2002).

\subsection{IOCM Challenges}

Although it has been argued that IOCM practices have the potential to provide advantages to collaborating partners, these practices can confront firms with exchange hazards and expose them to risks due to the reluctance to share the information needed for cost minimization (Anderson and Dekker, 2009). This reluctance stems from the concern about equity and the sensitive nature of accounting information required. Thus, Anderson and Dekker (2009) stated that appropriate safeguards and incentives are required to share accounting information and stimulate active engagement by partners in cost reduction activities. Therefore, a value creation perspective has been emphasized in IOCM studies by focusing on the prospect of potential collaborative advantages. Similarly, Chenhall (2006) argued that motivating partners to enhance their own returns in a manner that increases rather than decreases returns for the entire value chain may be recognized as a unique challenge of managing costs across firms' boundaries. In addition, Cooper and Slagmulder (2004) indicated that if one of the firms encountered an engineering challenge, it is not unusual for engineers from other firms in the chain to help solve the problem.

A recent study by Farias and Gasparetto (2016) sought to highlight the difficulties and factors relating to IOCM. The study divided these factors into three groups. First, factors relating to the formation of collaborative relationships and strategies of firms, such as the lack of resources to execute the project and differences between the strategic plans of firms. Second, factors relating to the development of processes and construction of relationships. These include factors, such as lack of trust among the partners and opportunism. Third, factors relating to the results, reviews, and adjustments that occur in relationships, such as lack of regular performance reviews and uneven distribution of benefits.

\subsection{Case-Based Studies}

In response to the theoretical claims, researchers started to empirically examine the implications of IOCM and the contextual factors that may influence its 
implementation. A considerable number of studies that have been reviewed focused on IOCM in inter-organizational relationships. This reflects the fact that IOCM has received increased attention from different industries and across numerous countries (Håkansson and Lind, 2006). However, it is necessary to admit that consistent practices of IOCM have not yet emerged (Fayard et al., 2012; Möller et al., 2011; Windolph and Möller, 2012). Therefore, IOCM is determined by the extent to which joint cost saving activities are undertaken by suppliers and buyers in interorganizational relationships. The review includes two Danish studies by Mouritsen et al. (2001) and Jakobsen (2010); two Japanese studies by Cooper and Slagmulder (2004), and Cooper and Yoshikawa (1994); two Finnish studies by Kulmala (2004; 2007); one German and Finnish study by Kajüter and Kulmala (2005); one Swedish study by Agndal and Nilsson (2009); and one Korean study by Sohn et al. (2014).

The review of the literature indicated that most of the case studies recognized the positive effect of IOCM on cost reduction. This view began with Cooper and Yoshikawa (1994) who emphasized that IOCM practices are designed to create downward cost pressure on the entire supplier chain. Based on the TokyoYokohama-Kamakura supplier chain case from Japan, the study argued that these practices relieve sales of the responsibility for pressuring manufacturing on cost, and allow them to focus on other areas of coordination between the functions. Particularly, Cooper and Yoshikawa emphasized that IOCM practices are designed to achieve three purposes. First, they create conduits that transmit the competitive pressures faced by the buyer (Tokyo). Second, they create the ability for the product engineers to jointly design products that can be manufactured more cost efficiently than if they acted independently. Thirdly, through trade-off techniques, IOCM practices create a way for product specifications that Tokyo sets for the items that it purchases to be amended. These amendments allow the final product to be sold at its target price while still generating adequate returns for Tokyo, Yokohama, and Kamakura.

Looking at two firms, Mouritsen et al. (2001) discussed the adoption of target cost management and OBA. Although both firms were successful, it is stated that they experienced a crisis - a gap in knowledge, insight, and control - after outsourcing parts of their processes. Thus, firms have begun to develop target cost management and OBA to keep in touch with the processes. Overcoming absence and creating closeness and trust-relations to produce a more competitive supplier relationship were the effective results of OBA. In one case, the adoption of target costing management was not in its full complements, but only through its functional analysis component. However, functional analysis was appropriate for controlling the supplier's development process as it encourages the firm and its supplier to engage in a systematic discussion about the functionality of the design. As a result, cost reduction projects can be introduced based on the new adjustments and interventions made under these inter-organizational accounting systems.

Continuing the positive theme of IOCM, Eurocar "international manufacturer of passenger cars" has adopted IOCM since the 1990s due to the large number of outsourced items (Kajüter and Kulmala, 2005). This approach is called total cost management that aims at analysing and managing costs within the supply chain 
based upon cooperative and stable relationships with the suppliers. Eurocar recognized that this approach with the joint commitment of the supplier and the buyer helps in identifying opportunities for cost reduction. The same conclusion was drawn from a case study on dual Finnish SME networks. Kulmala et al. (2007) analysed the implementation of IOCM practices in networks, and cost reduction was introduced as the main objective to be achieved. The study emphasized that the main contractors should support the development, implementation, and utilization of IOCM practices. Thus, these practices opened a new way for the contractors to increase their awareness of cost structures, which, in turn, helped identify additional cost reduction opportunities among the SME firms. However, the study indicated that management accounting practices in networks are influenced by factors, such as firm size, network infrastructure and the variety of processes among the network members. In addition, the development of these practices depends on the simplicity and degree of standardization of the processes of the network members.

Despite evidence concerning the positive impact of IOCM, various disadvantages were admitted by some studies. In an exploratory field-based research on three Japanese manufacturing firms with their first and second-tier suppliers, Cooper and Slagmulder (2004) provided insights into firms' IOCM practices and the relational context associated with these practices. Particularly, the selected firms had adopted IOCM practices to find lower cost solutions to overcome the information asymmetry between the supplier and the buyer. However, IOCM practices were based on the relational context and the degree of interaction between the supplier and the buyer. Despite the advantages of finding lower cost solutions, the study recognized that undertaking IOCM practices is associated with additional complexities. These include the costs associated with IOCM intervention involving the time and effort spent by the supplier's team discussing and negotiating solutions with the buyer's team, as well as the costs of formalizing any changes to the design of the outsourced item(s) and the final product. This refers to the issue of contextual and relational factors, and their relation to the implementation and implications of IOCM practices. In fact, these factors have been addressed in relation to outsourcing, cost accounting systems and inter-organizational accounting systems (e.g. Artz and Brush, 2000; Ax, Greve, and Nilsson, 2008; Baines and LangfieldSmith, 2003; Chenhall and Langfield-Smith, 1998; Ferrer, Santa, Hyland, and Bretherton, 2010; Henri and Journeault, 2008; Innes, Mitchell, and Sinclair, 2000; Ittner, Lanen, and Larcker, 2002; Levy, 1995; Malmi, 1999).

In sum, although case-based studies have argued that IOCM can help in reducing cost through reducing information asymmetries and identifying lower cost opportunities, these studies lack generalizability since they only represent the selected cases. In addition, the effect of different contextual relational factors has still not been examined to show their impact on IOCM practices (Windolph and Möller, 2012). Therefore, a quantitative study with statistical analysis is required to provide more generalizability of the findings (Kulmala et al., 2007) 


\subsection{Survey-Based Studies}

To date and to our knowledge, a quantitative research on the direct relationship between IOCM and cost reduction is still absent. However, some quantitative research, including investigating supplier collaboration (Oh and Rhee, 2010), transition of buyer-supplier relationships (Kawai, Sakaguchi, and Shimizu, 2013), inter-organizational corporation (Yu and Chen, 2013), and IOCM (Fayard et al., 2012; Möller et al., 2011; Windolph and Möller, 2012) are reviewed in the following section.

In general, prior studies argued that some advantages can be achieved from inter-organizational collaboration. A survey on the Korean automotive parts industry, for example, was conducted by Oh and Rhee (2010) to address the impact of supplier collaboration (collaborative communication, collaboration development, collaborative problem solving and strategic purchasing) on competitive advantages. The findings suggested that collaboration in new car development positively influences carmakers competitive advantages. Particularly, supplier collaboration positively influences the performance of carmakers in terms of reduced development cost, time and risk, and quality improvement. However, this relationship is moderated by technological uncertainty.

Likewise, Kawai et al. (2013) investigated the transition of buyer-supplier relationships in Japanese manufacturing firms in the early 2000s. A survey of 335 firms including electrical/electronic, transportation, equipment machinery and precision industries was conducted. The study presented that Japanese firms have close relationships with their partners and that the sustainability of long-term relationships depends on the benefits gained from inter-organizational collaboration. These benefits include sending engineers to suppliers, attending suppliers' meetings and proposing cost saving ideas. Emphasizing the positive effect view, Yu and Chen (2013) used the transaction cost perspective to investigate the influence of inter-organizational cooperation on the organizational performance of the healthcare industry. The empirical investigation of 382 hospitals in Taiwan indicated that inter-organizational cooperation has a positive influence on hospital performance.

Particularly, the quantitative research on IOCM focused on the factors affecting its implementation and implications in supplier-buyer relationships. Three studies, including Fayard et al. (2012), Fayard et al. (2012), and Windolph and Möller (2012), were detected in prior research. Fayard et al. (2012) argued that IOCM is a firm's resource that helps firms to achieve competitive advantages. Using a survey of firms' managerial accountants, the study reported that internal electronic integration, external electronic integration, absorptive capacity and internal cost management are interrelated resources, which can be useful in enabling firms to ultimately benefit from managing inter-organizational costs. In other words, firms seeking to develop IOCM would likely benefit by ensuring they have a strong internal electronic integration, a strong internal cost management resource, and a strong absorptive capacity. In addition, Möller et al. (2011) emphasized the buyer's commitment as a significant relational safeguard to implement IOCM. This is because buyer's commitment entails the intention of the buyer to continue the 
relationship in the long term, thus, reducing the uncertainty of its future actions due to the buyer's long-run orientation towards the relationship.

Windolph and Möller (2012) mailed a questionnaire to 733 automotive suppliers in the Association of German Automobile Manufacturers to examine the impact of IOCM on supplier relationship satisfaction. The study reported that IOCM is positively related to supplier relationship satisfaction as buyers strongly support suppliers in improving their quality, productivity, and efficiency. The findings suggested that relational social norms and buyers' opportunism did not moderate the relationship between IOCM and supplier relationship satisfaction.

In contrast to the argument above, which emphasizes the positive impact of IOCM, some empirical research found that firms' alliances may increase the coordination cost. For example, Gulati and Singh (1998) argued that in an alliance that consists of two firms, the greater the need for joint decision-making and ongoing task coordination between the partners, the higher the anticipated level of the coordination cost. Similarly, Kim (2007), and Xu and Beamon (2006) argued that the increase in the coordination costs between partners is due to the cost of the information and relation processes. Based on the argument above, it seems timely to carry out a quantitative study to look directly at the relationship between IOCM and cost reduction. A summary of conceptual, case-based and survey-based studies is provided in Table 2.2 .

\section{OBA Studies}

In this section, conceptual and empirical studies on OBA were reviewed to provide a basic understanding of OBA and its impact on supplier-buyer relationships.

\subsection{Brief Sketch}

This section reviews studies on OBA to provide definitions, practices, dimensions, implications and challenges as reported in the literature.

The disclosure and sharing of accounting information in supplier-buyer relationships refer to the practice of OBA. The characterization of OBA has been the subject of a long argument as different authors indicate different kinds of information and data when employing this term. For instance, Lamming (1993) defined OBA as the sharing of costing information between the supplier and buyer that would have remained undisclosed by both partners for the use of negotiations. Similarly, Hoffjan and Kruse (2006) argued that sharing cost information represents the essence of OBA. In contrast, some authors introduced OBA with a broader definition that includes exchanging management accounting information (financial and non-financial) between the supplier and the buyer. For example, Tomkins (2001) argued that sharing inter-organizational information refers to business information, which includes information on price, quality, delivery terms, research and development, cost structures, and target costs. In addition, Carr and $\mathrm{Ng}$ (1995), and Mouritsen et al. (2001) emphasized cost structure, set-ups, capacity saturation, cycle and movement times and delivery information. In a similar manner, Kajüter and Kulmala (2005) analysed OBA practices using cost information and non- 
financial information. Recently, Caglio and Ditillo (2012b) conceptualized OBA as management accounting information exchanged between collaborating firms. Table 3.1 provides a summary of the types of information disclosed as OBA practices found in previous studies.

Table 2.2: Summary of Previous Studies on IOCM

\begin{tabular}{l}
\hline Authors \\
\hline Conceptual \\
Cooper and Slagmulder \\
(1999) \\
Kajiiter (2002) \\
Seuring (2002) \\
Slagmulder (2002) \\
Anderson and Dekker \\
(2009)
\end{tabular}

Chen (2011) Major Findings

Introducing the term of IOCM with its definition.

IOCM practices may lead to reduced costs in supplier-buyer relationship. Developing a framework for supply chain costing.

IOCM should start as a cultural process with the appropriate supplier-buyer relationships. IOCM confronts firms with exchange hazards and exposes them to risks. Appropriate safeguards and incentives are required to share accounting information and stimulate active engagement by partners in cost reduction activities.

Attempt to develop a framework to understand IOCM based on accounting data disclosure (nature, use, and conditions), which is recognized as a critical foundation for IOCM implementation.

Surowiec (2013)

IOCM requires buyers to determine the specific goals of cost reduction with suppliers and collaborate with them to find ways to lower costs.

Uddin (2013)

IOCM practices include target costing, functionality price quality trade-offs, interorganizational cost investigation, concurrent cost management, kaizen costing or continuous improvement, minimum cost investigation, internal cost management, OBA, value chain analysis and information sharing.

Case-based studies

Cooper and Yoshikawa (1994)

Mouritsen et al. (2001)

Cooper and Slagmulder (2004)

Kajüter and Kulmala (2005)

Kulmala (2004)

Kulmala et al. (2007)

Agndal and Nilsson (2009)

Survey-based studies Möller et al. (2011) Fayard et al. (2012)

Windolph and Möller (2012)
IOCM is designed to create downward cost pressures on the entire supplier chain. It relieves sales of the responsibility for pressuring manufacturing on costs and allows them to focus on other areas of coordination between the functions.

Target cost management and OBA helps buyers to keep in touch with suppliers and create closeness and trust-relations to produce a more competitive supplier relationship. Cost reduction projects can be introduced under these accounting systems.

Although IOCM helps in finding lower cost solutions, it is associated with additional complexities and additional costs.

IOCM with the joint commitment of the supplier and the buyer assist in identifying and implementing opportunities to cost reduction.

Cost reduction target including cost reduction for the production, total purchasing costs of a product group and total costs are the reasons behind IOCM implementation.

IOCM practices opened a new way to contractors to increase the awareness of cost structures and to identify additional cost reduction opportunities among the SMEs.

IOCM activities, such as supplier selection, joint product design, and joint manufacturing process development, offer important opportunities for cost reduction on the final costs of the products.

Buyer's commitment is a significant relational safeguard to implement IOCM.

IOCM is a firm's resource that requires internal electronic integration, external electronic integration, absorptive capacity and internal cost management.

IOCM is positively related to supplier relationship satisfaction. This relationship is moderated by relational social norms and buyers' opportunism.

OBA is characterized by the amount, quality, and frequency of the information shared between the supplier and the buyer (Möller et al., 2011). The literature identifies OBA practices based on three dimensions: 1) the direction of the information exchange, 2) the quality and degree of disclosure, and 3) the boundaries openness (Windolph and Möller, 2012). The direction of sharing information can be unilateral or bidirectional where the supplier opens its management accounting information to the buyer or both partners open their books (Hoffjan and Kruse, 2006; Lamming, 1996; McIvor, 2001). The level and type of information disclosed by the supplier reflect the quality and degree of information disclosure, which, in 
turn, depends on the exchange relationship and adoption purpose (Windolph and Möller, 2012). Axelsson, Laage-Hellman, and Nilsson (2002) argued that OBA ranges from disclosing the data used and available in the internal accounting system of the firm to disclosing relatively unspecific cost data (related process information). The boundaries openness can differentiate OBA practices since information sharing occurs in a network-wide or in a dyadic supplier-buyer relationship (Windolph and Möller, 2012).

Table 3.1: Type of Data Shared as OBA Practices Based on Previous Studies

\begin{tabular}{|c|c|}
\hline Authors & IOCM Practices \\
\hline $\begin{array}{l}\text { Carr and } \mathrm{Ng}(1995) \\
\text { Axelsson et al. (2002), } \\
\text { Ellram (1996), Seal et } \\
\text { al. (1999), Singh et al. } \\
(2012)\end{array}$ & $\begin{array}{l}\text { 1) Packaging and shipping costs, 2) Material costs, 3) Overhead costs, 4) Profit margin } \\
\text { 1) Cost data }\end{array}$ \\
\hline $\begin{array}{l}\text { Mouritsen et al. } \\
(2001)\end{array}$ & $\begin{array}{l}\text { 1) Cost structures, 2) Material flows, 3) Adjustment times for assembling machines, 4) The } \\
\text { size of the intermediate product inventory, 5) Rate of turnover }\end{array}$ \\
\hline $\begin{array}{l}\text { Kajüter and Kulmala } \\
(2005)\end{array}$ & 1) Cost elements, 2) Profit margin. 3)Sales forecasts, 4) Operating data, 5) Technical expertise \\
\hline $\begin{array}{l}\text { Agndal and Nilsson } \\
(2010)\end{array}$ & $\begin{array}{l}\text { 1) Cost elements, 2) Costs related to buyer-supplier interface, 3) Detailed data on production } \\
\text { processes, 4) General supplier data, 5) Supply chain data }\end{array}$ \\
\hline $\begin{array}{l}\text { Hoffjan, Lührs, and } \\
\text { Kolburg (2011) }\end{array}$ & 1) Materials costs 2) Production costs, 3) Cost of items, 4) Overhead costs, 5) Profits \\
\hline $\begin{array}{l}\text { Caglio and Ditillo } \\
(2012 b)\end{array}$ & 1) Management accounting information \\
\hline $\begin{array}{l}\text { Romano and } \\
\text { Formentini (2012) }\end{array}$ & $\begin{array}{l}\text { 1) Detailed estimations on materials, labour and overhead costs, 2) Detailed estimations } \\
\text { purchasing and supply management costs, 3) Aggregated cost data on raw materials, labour } \\
\text { and inventory, 4) Costs for quality control, special tools and equipment }\end{array}$ \\
\hline Alenius et al. (2015) & 1) Financial information, 2) Non-financial information \\
\hline
\end{tabular}

\subsection{OBA and Cost Reduction}

Information is considered to be an essential component of the daily exchanges between firms and individuals (Cheshire, 2007). All purchase transactions involve an information exchange between suppliers and buyers, and, typically, this information consists of the prices, product specifications, delivery schedules, longterm forecasting, structural planning information, future product design information and so on (Noordewier, John, and Nevin, 1990). The importance of sharing information in the supply chain is increasingly recognized as a critical success factor. It is generally suggested that effective information sharing allows the supply chain to generate higher performance through operating more efficiently. Thus, it has become a critical factor for improving supply chain performance (Chu and Lee, 2006; Dyer, Kale, and Singh, 2001; Zhou and Benton, 2007). Håkansson and Lind (2004) stated that it is not enough to know about the resources or activities of the counterpart, instead, comprehensive information about specific activities, such as costs, revenues, cycle time, reliability and quality will be needed for partners to improve their operations.

The purpose of OBA is to facilitate cooperation between the supplier and buyer leading to the identification of subsequent cost reduction potential (Axelsson et al., 2002). Likewise, Ellram (1996) stated that suppliers need to open their internal accounting books to the buyers in order to identify high-cost areas so the total costs can be reduced. Thus, it is viewed as a valuable tool for both supplier and 
buyer that require presenting cost data in a form based on predetermined assumptions. Furthermore, Lamming et al. $(2004 ; 2005)$ argued that managers can employ transparency as a basis for sharing tacit knowledge and sensitive information, as it is seen as being a manageable element in the supplier-buyer relationship. Therefore, significant benefits can accrue to the firms as a result.

Håkansson and Lind (2006), and Madlberger (2010) emphasized the importance of OBA as a cost reduction technique that can be used by partners. Particularly, the detailed breakdown of information makes it possible to identify cost elements and assists in identifying cost reduction solutions (Kajüter and Kulmala, 2005). According to Agndal and Nilsson (2010), OBA can support the development of cost-efficient products and manufacturing processes, achieve price control (cost-based pricing), and communicate expectations regarding future price reductions. Thus, OBA can be seen as being a costing template or representation of organizational control or both. In other words, OBA is viewed as being a vehicle for setting costs and activity standards or performance targets as well as a means to monitor conformance to the standards set (Roberts et al., 2010).

\subsection{OBA Challenges}

Despite the proposed benefits of OBA in the supplier-buyer relationship, the exchange of sensitive information may increase the risk of opportunistic behaviour by the partner in using the available information. This will increase the suppliers' concern that the buyers may exploit this information to enforce price decreases (Carr and Ng, 1995; Munday, 1992). This concern indicates that OBA has a negative effect on the satisfaction of the suppliers' relationship (Windolph and Möller, 2012). This is because suppliers may not directly benefit from OBA when the buyers use disclosed data to decrease the supplier's profit margin. Furthermore, suppliers perceive the request for cost data disclosure as a signal of buyer's distrust regarding adequate cost allocation. In addition, data misuse would quickly reduce buyers standing in the eyes of the suppliers and would therefore negatively impact the ability of the buyers to efficiently develop products together with other suppliers (Agndal and Nilsson, 2010).

\subsection{Case-Based Studies}

Considering the primary goal of OBA, it is surprising that little empirical evidence has been conducted on understanding the implications of OBA (Kajüter and Kulmala, 2005; Kulmala et al., 2002). Windolph and Möller (2012) stated that notwithstanding the important role of OBA in inter-organizational relationships, there is little research addressing the actual impact of OBA on the supplier-buyer relationship. Although some researchers employed different terms in dealing with disclosure of cost information, such as open book costing (McIvor, 2001), OBA (Kulmala et al., 2002; Mouritsen et al., 2001), open book negotiation (Lamming et al., 2005), and open book policy (Agndal and Nilsson, 2008), these terms share the same concern about cost information disclosure between suppliers and buyers. Table 3.2 provides a summary of the conceptual and empirical studies on OBA. To date, OBA has been addressed in some case studies to illustrate its nature and 
investigate its implications. The work by Carr and $\mathrm{Ng}$ (1995) was a pioneer study on the use of OBA between Nissan and its UK suppliers. The study found that some suppliers provided Nissan with detailed breakdowns "disclosure to Nissan is $100 \%$ " of components' cost structure. Browns firm (supplier of Nissan) claimed that they had found distinct benefits from disclosing information to Nissan. The study reported that Browns' Financial Controller mentioned that when the price of raw materials increases, they could find a way to negotiate with Nissan. Thus, both partners can reduce costs through reducing the supplier costs not the margin. However, Browns emphasized the role of trust for operating the open book successfully. In another UK case study on two manufacturing firms, Seal et al. (1999) reported that firms aimed to implement an open book agreement, which includes knowledge of the supplier's costing methodology. This agreement involves the sharing of technical information about new products, which seemed less of a problem since the benefits will be shared between the partners. Nevertheless, there was no actual implementation of OBA due to the weaknesses in the internal cost accounting systems of the partners.

Table 3.2: Summary of Previous Studies on OBA

\begin{tabular}{|c|c|}
\hline Authors & Major Findings \\
\hline \multicolumn{2}{|l|}{ Conceptual } \\
\hline Lamming (1993) & $\begin{array}{l}\text { Introduce the definition of OBA as the sharing of costing information between supplier and } \\
\text { buyer that would have been remained undisclosed by both partners for use in negotiations. }\end{array}$ \\
\hline Ellram (1996) & $\begin{array}{l}\text { Open book approach requires the suppliers to open their internal accounting books to the } \\
\text { buyer in order to identify high-cost areas so the reduced costs can be shared. }\end{array}$ \\
\hline $\begin{array}{l}\text { Håkansson and Lind } \\
(2004)\end{array}$ & $\begin{array}{l}\text { Partners need to know about counterpart resources, specific activities, such as costs, } \\
\text { revenues, cycle time, reliability and quality, in order to improve their operations. }\end{array}$ \\
\hline \multicolumn{2}{|l|}{ Case-based studies } \\
\hline Carr and $\mathrm{Ng}(1995)$ & $\begin{array}{l}\text { Disclosing information from the suppliers to the buyers achieves "distinct benefits" with } \\
\text { some concern of being pressed heavily to reduce costs by the buyer. }\end{array}$ \\
\hline Seal et al. (1999) & $\begin{array}{l}\text { OBA includes sharing of technical information about new products. The implementation } \\
\text { required internal cost accounting system. }\end{array}$ \\
\hline Mouritsen et al. (2001) & OBA helps to save time and costs very concretely. \\
\hline Dekker (2003) & $\begin{array}{l}\text { Costs can be managed through integrating cost data across the supply chain - cost model-to } \\
\text { analyse, calculate and monitor the supply chain cost over time. }\end{array}$ \\
\hline $\begin{array}{l}\text { Kajüter and Kulmala } \\
(2005)\end{array}$ & OBA is practiced within the network to identify cost reduction potentials. \\
\hline $\begin{array}{l}\text { Agndal and Nilsson } \\
\text { (2010) }\end{array}$ & $\begin{array}{l}\text { The purposes of disclosing cost data are (1) achieving cost efficient products, (2) supporting } \\
\text { cost reductions opportunities of products, (3) achieving price control (cost-based pricing). }\end{array}$ \\
\hline $\begin{array}{l}\text { Caglio and Ditillo } \\
(2012 a)\end{array}$ & $\begin{array}{l}\text { OBA has an integrative role in inter-organizational relationships. It helps in carrying out } \\
\text { operations and in collaborating for the achievement of the product. }\end{array}$ \\
\hline Alenius et al. (2015) & $\begin{array}{l}\text { OBA plays a crucial role in creating and managing the supplier-buyer relationships. It is a } \\
\text { tool that guides firms in what to prioritize and in how to identify where to improve sales in } \\
\text { the related relationships. }\end{array}$ \\
\hline \multicolumn{2}{|l|}{ Survey-based studies } \\
\hline Munday (1992) & Disclosure of cost data mainly leads to pressure on the contract or quoted prices. \\
\hline McIvor (2001) & $\begin{array}{l}\text { Disclosed cost data is used by buyers to erode suppliers' profit margin by threatening to alter } \\
\text { the supply arrangement. }\end{array}$ \\
\hline Wagner (2008) & OBA has a positive influence on firm's supply chain performance. \\
\hline Yigitbasioglu (2010) & $\begin{array}{l}\text { Sharing information between buyers and their key suppliers has a positive effect on } \\
\text { performance resources, performance output, and performance flexibility. }\end{array}$ \\
\hline $\begin{array}{l}\text { Windolph and Möller } \\
\text { (2012) }\end{array}$ & $\begin{array}{l}\text { OBA negatively affects suppliers' relationship satisfaction. The suppliers do not directly } \\
\text { benefit from OBA. }\end{array}$ \\
\hline
\end{tabular}

More detailed studies on OBA were carried out by Mouritsen et al. (2001), and Kajüter and Kulmala (2005). Looking at a Danish firm, LeanTech, who 
implemented OBA with its suppliers, Mouritsen et al. (2001) conducted a case study on how OBA is implemented. Using OBA, suppliers can be benchmarked and the suppliers' production and distribution processes can be redesigned. Therefore, OBA is recognized as being a cooperation strategy between partners where the information disclosed is used to influence the flow of products and services among firms in a supply chain. Therefore, new interventions and adjustments can be made to begin cost saving. This is because the sharing of information allows for the construction of a whole new space for cost management, as more elements can be inserted into one planning mechanism. However, these arrangements require a highly developed sense of trust between the partners involved.

The investigation concerning the understanding of the ability of OBA to help partners to identify cost-reduction opportunities was later continued. Kajüter and Kulmala (2005) conducted a detailed investigation on the use of OBA in a single case study of a German car manufacturer - Eurocar - and its supplying network. Due to the large number of outsourced items, Eurocar cooperates and is involved in the early stages of product development with about 50 key suppliers. Thus, to identify cost reduction potentials, OBA is practiced within the network. Eurocar created worksheets that determine the major cost elements (such as raw material, labour, overheads, packaging, transportation, warranty, research and development) to be disclosed at different stages of the network. These detailed cost breakdowns make it possible to identify important cost elements and assist in identifying cost reduction opportunities. To do so, the cost structure analysis is combined with an investigation of cost drivers that drive up costs without adding value for the customers. These include drivers, such as over-specification of materials, prototype policy, and product complexity. The identification of such drivers can generate ideas for improving the cost structure. Dekker (2003) reached similar conclusions concerning the use of OBA within Sainsbury's and its larger suppliers. Cooperatively, Sainsbury's and its suppliers managed the costs by integrating cost data across the supply chain - cost model - to achieve three main purposes. First, analysing the cost performance of supply chain activities. Second, calculating the cost consequences of changing supply chain operations in order to improve the operations and reduce costs. Third, monitoring on a periodic basis the development of supply chain costs over time. Although the cost model aims to identify the inefficiencies of suppliers, Sainsbury's emphasized that it is not used in an opportunistic way. Thus, clear agreements were made with the suppliers concerning the manner that the information and outcomes of the cost model should be used. Therefore, any cost saving opportunities would be realized, leaving all parties better off. However, the sharing of sensitive information (OBA) reflects the supplier's trust and buyer's commitment about the use of the shared information.

Alenius et al. (2015) argued that OBA (systematic disclosure of financial and non-financial information) plays a crucial role in creating and managing the supplier-buyer relationships. Furthermore, the indirect relationships and organizational and technical interfaces are influenced by the disclosure of information between suppliers and buyers. The study recognized OBA as a tool that guides firms in what to prioritize and in how to identify where to improve sales in 
the related relationships and not merely a tool that directs attention towards improving efficiency and cost cutting within a firm and its suppliers or buyers. They concluded that OBA is not simply about cost reduction, but about increasing the revenue obtained from key resources through the creation and exploration of new resource interfaces.

Despite the advantages OBA can introduce to the supplier-buyer relationship, the implementation of this practice is not consistent among different industries. Agndal and Nilsson (2010) carried out three case studies on the use of OBA in supplier relationships with three different cases including a vehicle maker, retailer and a telecommunications firm. In contrast to the supplier relationship of the telecommunications firm that was characterized by low organizational interdependencies, the relationships of the vehicle maker and retailer with their suppliers were strong emphasizing managing interdependencies. Therefore, the study found major differences in the OBA practices concerning the type, extent, form, direction, purposes, and uses of cost data disclosure among the three cases. The type of shared information, however, ranged from detailed cost breakdowns on the product's entire lifecycle in the case of the vehicle maker to associated cost drivers and data focusing on the processes in the buyer-supplier interface in the case of the retailer. The case of the telecommunications firm revealed disclosure of the estimated labour and overhead costs per service. Regarding forms of disclosed information, all three cases used standardized forms and detailed instructions with remarkably advanced practices by the vehicle maker. In addition, the three cases exhibited unidirectional (supplier to buyer) disclosure of cost data with limited feedback from the buyer of the telecommunications firm and extensive feedback from the buyers in the cases of the vehicle maker and retailer.

As a summary, with the use of OBA, prior case-based research illustrated both the advantages and disadvantages of this practice. Carr and $\mathrm{Ng}$ (1995) argued that "distinct benefits" can be achieved from disclosing information to Nissan. At the same time, the suppliers emphasized trust for OBA to operate. Thus, they believed that Nissan would not reduce their profit margin, and, instead, would seek to reduce costs through, for example, suggesting different and acceptable raw materials. Similarly, LeanTech commented on the benefits of OBA that they were able to save time and cost very concretely when they had introduced an open book arrangement with the suppliers (Mouritsen et al., 2001). Therefore, cost reduction in interorganizational relationships was recognized as being a key role of OBA. Eurocar, for example, used cost breakdowns to identify cost-reduction opportunities that can be found at any supplier within the network, or at the interface between the partners (Kajüter and Kulmala, 2005). Moreover, Caglio and Ditillo (2012a) argued that the disclosure of accounting information plays an integrative role. Therefore, OBA supports inter-organizational relationships by means of variance analysis and help in carrying out operations and in collaborating for the achievement of the final product. Agndal and Nilsson (2010) summarized the main purposes for disclosing the cost data for each case. In the vehicle maker case, the main goal was to achieve cost efficient products through target costing, value engineering, and kaizen. The disclosure of cost data from the suppliers of the retailer aims, to some extent, 
supported the cost reduction opportunities of products, such as using cheaper raw materials. Similarly, the suppliers of the telecommunications firm adopted OBA in order to achieve price control (cost-based pricing) and communicate expectations regarding future price reductions.

\subsection{Survey-Based Studies}

Apart from the case studies, not many studies have been published on the implications of OBA in the relationships of suppliers-buyers. Two survey-based studies have been carried out in the UK (McIvor, 2001; Munday, 1992), one in Switzerland (Wagner, 2008), one in Finland and Sweden (Yigitbasioglu, 2010) and one in Germany (Windolph and Möller, 2012).

The quantitative studies on OBA mainly focus on the buyers' behaviour in using the disclosed information. The findings from the UK studies report that the suppliers' disclosure of cost data mainly leads to pressure on the contract or quoted prices. However, Munday (1992) reported that this pressure is related to suggestions to use different materials, or to reduce the constituent costs in a different manner. Consistent with these findings, McIvor (2001) indicated that disclosed cost data is used by buyers to erode suppliers' profit margins by threatening to alter the supply arrangement. Thus, this conclusion is different from the proposition that reducing the price should be based on joint efforts at cost reduction. Although the UK studies introduced some evidence concerning the use of disclosed cost data, the findings acknowledged that this disclosure might lead to buyer opportunistic behaviour, which negatively influences the relational context. Although these studies emphasized the implementation and use of the disclosed cost data, they did not address the effect of OBA in detail with regard to the cost efficiency of the supplier-buyer relationship.

Consistent with the negative results of OBA practices, the findings from Germany indicated that OBA negatively affects the satisfaction of the suppliers' relationship. Windolph and Möller (2012) reported that suppliers do not directly benefit from OBA as was suggested by previous studies. These prejudices against OBA, however, were attributed to the opportunistic use of disclosed data by the buyer to decrease the supplier's profit margin. Furthermore, suppliers perceive the request for cost data disclosure as a signal of buyer's distrust regarding adequate cost allocation. Thus, Windolph and Möller (2012) argued that introducing OBA requires establishing adequate relational social norms to reduce the negative effect of OBA through reducing the perception of the buyers' opportunistic behaviour.

In contrast to the "negative" findings, the findings from Switzerland report that OBA has a positive influence on firm's supply chain performance. Despite these positive results, Wagner (2008) indicated that suppliers are still hesitant to disclose (confidential) information with buyers. Supporting these results, Yigitbasioglu (2010) revealed that sharing information between buyers and their key suppliers has a positive effect on performance resources, performance 
output, and performance flexibility. The study argued that the advantages of sharing information range from reducing uncertainty, improving decision making, reducing the bullwhip effect to relatively influencing customer satisfaction. Although the findings were investigated based on the data from Finland and Sweden, only the buyer's perspective was analysed, thus, the findings could be biased because the information is mainly disclosed by the suppliers.

\section{IOCM and OBA}

Prior studies addressing IOCM and OBA have investigated these terms simultaneously or separately. Studying IOCM and OBA simultaneously follows the argument that $\mathrm{OBA}$ is required to implement and use IOCM practices (Cooper and Slagmulder, 1999). Therefore, several studies recognized OBA as being central to the concept of IOCM (Coad and Cullen, 2006; Cooper and Slagmulder, 2004; Fayard et al., 2012; Kulmala et al., 2002; Lamming et al., 2005). This is because establishing routines for sharing information is seen as a critical factor for the success of the supplier-buyer relationship (Cooper and Yoshikawa, 1994; Mohr and Spekman, 1994). Consistently, Håkansson and Lind (2004) stated that buyers need detailed information about suppliers' specific activities, such as cost, quality, cycle time and delivery to determine ways for improving operations.

However, OBA is not required by all IOCM practices. Both target costing and functionality price quality trade-offs can be implemented without cost data disclosure, while inter-organizational cost investigation and concurrent cost management require the buyer to be aware of the supplier cost structure (Cooper and Slagmulder, 1999). In the case of target costing and functionality price quality trade-off practices, the supplier and buyer teams work independently, which reduces the required shared cost data. With inter-organizational cost investigation and concurrent cost management techniques, OBA plays a critical role in identifying cost saving opportunities (Axelsson et al., 2002; Kajüter and Kulmala, 2005).

Particularly, OBA is used to assist the buyers in determining the adequacy of the allocations for overhead costs (Möller et al., 2011; Windolph and Möller, 2012). Therefore, the implementation and use of OBA do not necessarily yield in subsequent IOCM practices in the supplier-buyer relationship (Windolph and Möller, 2012). In fact, the ideas that successful IOCM requires suppliers to share information with their buyers (Coad and Cullen, 2006; Cooper and Slagmulder, 2004) and that OBA is a prerequisite for IOCM implementation (Agndal and Nilsson, 2009; Ellram, 1996) have been acknowledged to be the decisive reasons for implementing OBA (Carr and Ng, 1995; Kajüter and Kulmala, 2005; Kulmala et al., 2002; Möller et al., 2011; Windolph and Möller, 2012). Therefore, IOCM and OBA are considered to be two independent cost 
management practices. Although their applications overlap, the expected benefits are at least partly interdependent (Windolph and Moeller 2012). Consequently, it is important to include both practices when examining their effects on cost reduction. This helps to identify the effect of each practice and avoid any bias in the findings since IOCM and OBA are supposed to be related to each other.

\section{Conclusion}

Recognizing the interdependence of action and the role that joint action can play in a firm's success, Hopwood (1996) called for more research on accounting beyond organizational boundaries. Although the significance of interorganizational accounting practices, such as IOCM and OBA, has been widely recognized in prior research, there is a lack of information concerning how these practices have been studied. Therefore, an attempt was made to fill the gap in the literature regarding these practices. The motivation of this paper was the need to assess research that has been carried out on IOCM and OBA as interorganizational accounting practices in the supplier-buyer relationship. Therefore, reviewing the literature is particularly significant given the growing role of these practices.

The findings of this review paper can be drawn as follows: first, the review of the literature indicated that studies in the US, UK, and Japan dominated the research on the area of IOCM and OBA, but, in recent years, more European and other countries have been involved. Second, the review indicated that the issues of IOCM and OBA are still mature, as most of the reviewed studies were qualitative. Third, the adoption of IOCM and OBA shows inconsistent practices and type of data exchanged between the partners. Generally, the practices of IOCM include target costing, functionality price quality trade-off, Interorganizational cost investigation, and concurrent cost management or some of these practices. OBA varies from disclosing cost data to the disclosure of management accounting information. Fourth, in terms of the role of IOCM and OBA to reduce the costs in the supplier-buyer relationship, from the review, it appeared that only conceptual and qualitative studies had addressed this issue. Some of these studies argued that IOCM and OBA can improve interorganizational relationships, particularly, when the partners develop relational safeguards to prevent opportunism. Nevertheless, the conclusions from these studies on the role of IOCM and OBA to reduce costs were contradictory. In addition, the generalizability of the results of these studies is limited to only the cases under investigation. Fifth, the review reported a limited number of quantitative studies that addressed IOCM and OBA but did not examine their effect on costs. Finally, this study introduced a comprehensive understanding of the concepts, adoption, and implications of IOCM and OBA. 
To provide generalizable findings, an empirical investigation under a quantitative approach is required to explore the practices of IOCM and OBA and to understand their role in managing costs in inter-organizational relationships.

\section{References}

Agndal, H., \& Nilsson, U. (2008). Supply chain decision-making supported by an open books policy. International Journal of Production Economics, 116(1), 154-167.

Agndal, H., \& Nilsson, U. (2009). Interorganizational cost management in the exchange process. Management Accounting Research, 20(2), 85-101.

Agndal, H., \& Nilsson, U. (2010). Different open book accounting practices for different purchasing strategies. Management Accounting Research, 21(3), 147166.

Alenius, E., Lind, J., \& Strömsten, T. (2015). The role of open book accounting in a supplier network: Creating and managing interdependencies across company boundaries. Industrial Marketing Management, 45, 195-206.

Anderson, S. W., \& Dekker, H. C. (2009). Accounting in networks: The transaction cost economics perspective. In H. Hakansson, Kraus, K. and Lind, J. (Eds) (Ed.), Accounting in Networks (pp. 235-268). Routledge, London.

Artz, K. W., \& Brush, T. H. (2000). Asset specificity, uncertainty and relational norms: an examination of coordination costs in collaborative strategic alliances. Journal of Economic Behavior and Organization, 41(4), 337-362.

Ax, C., Greve, J., \& Nilsson, U. (2008). The impact of competition and uncertainty on the adoption of target costing. International Journal of Production Economics, 115(1), 92-103.

Axelsson, B., Laage-Hellman, J., \& Nilsson, U. (2002). Modern management accounting for modern purchasing. European Journal of Purchasing and Supply Management, 8(1), 53-62.

Ba, S., \& Pavlou, P. A. (2002). Evidence of the effect of trust building technology in electronic markets: Price premiums and buyer behavior. MIS quarterly, 243268.

Baines, A., \& Langfield-Smith, K. (2003). Antecedents to management accounting change: a structural equation approach. Accounting, Organizations and Society, 28(7), 675-698.

Bastl, M., Grubic, T., Templar, S., Harrison, A., \& Fan, I.-S. (2010). Interorganisational costing approaches: the inhibiting factors. The International Journal of Logistics Management, 21(1), 65-88.

Belcourt, M. (2006). Outsourcing-The benefits and the risks. Human resource management review, 16(2), 269-279.

Bunduchi, R. (2005). Business relationships in internet-based electronic markets: the role of goodwill trust and transaction costs. Information Systems Journal, 15(4), 321-341. 
Caglio, A., \& Ditillo, A. (2012a). Interdependence and accounting information exchanges in inter-firm relationships. Journal of Management and Governance, 16(1), 57-80.

Caglio, A., \& Ditillo, A. (2012b). Opening the black box of management accounting information exchanges in buyer-supplier relationships. Management Accounting Research, 23(2), 61-78.

Cai, S., Yang, Z., \& Hu, Z. (2010). The effects of volume consolidation on buyersupplier relationships: A study of Chinese firms. Journal of Purchasing and Supply Management, 16(3), 152-162.

Carr, C., \& Ng, J. (1995). Total cost control: Nissan and its UK supplier partnerships. Management Accounting Research, 6(4), 347-365.

Chalos, P., \& O'Connor, N. (2005). The perceived effect of accounting controls on US-Chinese joint venture transaction costs and performance. Journal of International Accounting Research, 4(2), 53-73.

Chen, X. (2011). Interorganizational Cost Management in Supply Chain Based on Open Book Accounting. Paper presented at the Management and Service Science (MASS), 2011 International Conference on.

Cheng, J.-H. (2011). Inter-organizational relationships and knowledge sharing in green supply chains-Moderating by relational benefits and guanxi. Transportation Research Part E: Logistics and Transportation Review, 47(6), 837-849.

Chenhall, R. H. (2006). Theorizing contingencies in management control systems research. Handbooks of Management Accounting Research, 1, 163-205.

Chenhall, R. H., \& Langfield-Smith, K. (1998). Adoption and benefits of management accounting practices: an Australian study. Management Accounting Research, 9(1), 1-19.

Cheshire, C. (2007). Selective incentives and generalized information exchange. Social Psychology Quarterly, 70(1), 82-100.

Chu, W. H. J., \& Lee, C. C. (2006). Strategic information sharing in a supply chain. European Journal of Operational Research, 174(3), 1567-1579.

Clemons, E. K., \& Row, M. C. (1992). Information technology and industrial cooperation: the changing economics of coordination and ownership. Journal of Management Information Systems, 9(2), 9-28.

Coad, A. F., \& Cullen, J. (2006). Inter-organisational cost management: Towards an evolutionary perspective. Management Accounting Research, 17(4), 342369.

Cooper, R., \& Slagmulder, R. (1999). Supply chain development for the lean enterprise. Interorganizational cost management: Productivity Press, Portland, OR.

Cooper, R., \& Slagmulder, R. (2004). Interorganizational cost management and relational context. Accounting, Organizations and Society, 29(1), 1-26.

Cooper, R., \& Yoshikawa, T. (1994). Inter-organizational cost management systems: The case of the Tokyo-Yokohama-Kamakura supplier chain. International Journal of Production Economics, 37(1), 51-62. 
Cowen, T., \& Parker, D. (1997). Markets in the firm: a market-process approach to management: Institute of Economic Affairs, London.

Dekker, H., \& Smidt, P. (2003). A survey of the adoption and use of target costing in Dutch firms. International Journal of Production Economics, 84(3), 293305.

Dong, M. C., Ju, M., \& Fang, Y. (2016). Role hazard between supply chain partners in an institutionally fragmented market. Journal of Operations Management, 46, 5-18.

Dyer, J. H., \& Hatch, N. W. (2006). Relation-specific capabilities and barriers to knowledge transfers: creating advantage through network relationships. Strategic Management Journal, 27(8), 701-719.

Dyer, J. H., Kale, P., \& Singh, H. (2001). How to make strategic alliances work. MIT Sloan management review, 42(4), 37.

Ellram, L. M. (1996). A structured method for applying purchasing cost management tools. International Journal of Purchasing and Materials Management, 32(4), 11-19.

Farias, R. A. S., \& Gasparetto, V. (2016). Inhibiting Factors of Inter-organizational Cost Management Complementary Study. International Business Research, 9(8), 91 .

Fayard, D., Lee, L. S., Leitch, R. A., \& Kettinger, W. J. (2012). Effect of internal cost management, information systems integration, and absorptive capacity on inter-organizational cost management in supply chains. Accounting, Organizations and Society, 37(3), 168-187.

Ferrer, M., Santa, R., Hyland, P. W., \& Bretherton, P. (2010). Relational factors that explain supply chain relationships. Asia Pacific Journal of Marketing and Logistics, 22(3), 419-440.

Frances, J., \& Garnsey, E. (1996). Supermarkets and suppliers in the United Kingdom: System integration, information and control. Accounting, Organizations and Society, 21(6), 591-610.

Ghodeswar, B., \& Vaidyanathan, J. (2008). Business process outsourcing: an approach to gain access to world-class capabilities. Business Process Management Journal, 14(1), 23-38.

Gietzmann, M. B. (1996). Incomplete contracts and the make or buy decision: governance design and attainable flexibility. Accounting, Organizations and Society, 21(6), 611-626.

Gulati, R., Lawrence, P. R., \& Puranam, P. (2005). Adaptation in vertical relationships: Beyond incentive conflict. Strategic Management Journal, 26(5), 415-440.

Gulati, R., \& Singh, H. (1998). The architecture of cooperation: Managing coordination costs and appropriation concerns in strategic alliances. Administrative Science Quarterly, 781-814.

Håkansson, H., \& Lind, J. (2004). Accounting and network coordination. Accounting, Organizations and Society, 29(1), 51-72.

Håkansson, H., \& Lind, J. (2006). Accounting in an interorganizational setting. Handbooks of Management Accounting Research, 2, 885-902. 
Hanf, J., \& Dautzenberg, K. (2007). A theoretical framework of chain management. Journal on Chain and Network Science, 6(2), 79-94.

Henri, J.-F., \& Journeault, M. (2008). Environmental performance indicators: An empirical study of Canadian manufacturing firms. Journal of Environmental Management, 87(1), 165-176.

Hoffjan , A., \& Kruse, H. (2006). Open book accounting in supply chains-When and how is it used in practice? Journal of Cost Management, 20(6), 40-47.

Hoffjan, A., Lührs, S., \& Kolburg, A. (2011). Cost Transparency in supply chains: demystification of the cooperation tenet. Schmalenbach Business Review, 63, 230-251.

Hopwood, A. G. (1996). Looking across rather than up and down: on the need to explore the lateral processing of information. Accounting, Organizations and Society, 21(6), 589-590.

Innes, J., Mitchell, F., \& Sinclair, D. (2000). Activity-based costing in the UK's largest companies: a comparison of 1994 and 1999 survey results. Management Accounting Research, 11(3), 349-362.

Ittner, C. D., Lanen, W. N., \& Larcker, D. F. (2002). The association between activity-based costing and manufacturing performance. Journal of Accounting Research, 711-726.

Jakobsen, M. (2010). Management accounting as the inter-organisational boundary. Journal of Accounting and Organizational Change, 6(1), 96-122.

Jiang, B., Belohlav, J. A., \& Young, S. T. (2007). Outsourcing impact on manufacturing firms' value: Evidence from Japan. Journal of Operations Management, 25(4), 885-900.

Jones, C. S. (1999). Hierarchies, networks and management accounting in NHS hospitals. Accounting, Auditing and Accountability Journal, 12(2), 164-188.

Kajiiter, P. (2002). Proactive cost management in supply chains. In S. a. G. Seuring, M. (Ed.), Cost Management in Supply Chains (pp. 31-51): Physica, Heidelberg.

Kajüter, P., \& Kulmala, H. I. (2005). Open-book accounting in networks: Potential achievements and reasons for failures. Management Accounting Research, 16(2), 179-204.

Kawai, T., Sakaguchi, J., \& Shimizu, N. (2013). Transition of buyer-supplier relationships in Japan: Empirical evidence from manufacturing companies. Journal of Accounting and Organizational Change, 9(4), 427-447.

Kim, S. K. (2007). Relational behaviors in marketing channel relationships: Transaction cost implications. Journal of Business Research, 60(11), 1125 1134.

Kulmala, H. I. (2004). Developing cost management in customer-supplier relationships: three case studies. Journal of Purchasing and Supply Management, 10(2), 65-77.

Kulmala, H. I., Kajüter, P., \& Valkokari, K. (2007). Inter-organizational Cost Management in SME Networks. Paper presented at the Proceedings of the 8th Manufacturing Accounting Research Conference, Trento, Italy. 
Kulmala, H. I., Paranko, J., \& Uusi-Rauva, E. (2002). The role of cost management in network relationships. International Journal of Production Economics, 79(1), 33-43.

Lamming, R. (1993). Beyond partnership: strategies for innovation and lean supply (Vol. 94): Prentice Hall London.

Lamming, R. (1996). Squaring lean supply with supply chain management. International Journal of Operations and Production Management, 16(2), 183196.

Lamming, R., Caldwell, N., \& Harrison, D. (2004). Developing the concept of transparency for use in supply relationships. British Journal of Management, 15(4), 291-302.

Lamming, R., Caldwell, N., Phillips, W., \& Harrison, D. (2005). Sharing Sensitive Information in Supply Relationships: The Flaws in One-way Open-book Negotiation and the Need for Transparency. European Management Journal, 23(5), 554-563.

Levy, D. L. (1995). International sourcing and supply chain stability. Journal of International Business Studies, 343-360.

Li, W., Humphreys, P. K., Yeung, A. C., \& Cheng, T. (2012). The impact of supplier development on buyer competitive advantage: A path analytic model. International Journal of Production Economics, 135(1), 353-366.

Madlberger, M. (2010). What drives firms to engage in interorganizational information sharing in supply chain management? E-Collaboration Technologies and Organizational Performance: Current and Future Trends: Current and Future Trends, 101.

Mahmoodzadeh, E., Jalalinia, S., \& Nekui Yazdi, F. (2009). A business process outsourcing framework based on business process management and knowledge management. Business Process Management Journal, 15(6), 845-864.

Malmi, T. (1999). Activity-based costing diffusion across organizations: an exploratory empirical analysis of Finnish firms. Accounting, Organizations and Society, 24(8), 649-672.

McIvor, R. (2001). Lean supply: the design and cost reduction dimensions. European Journal of Purchasing and Supply Management, 7(4), 227-242.

Milgrom, P. R., \& Roberts, J. (1992). Economics, organization and management: Prentice-Hall International.

Mohr, J., \& Spekman, R. (1994). Characteristics of partnership success: partnership attributes, communication behavior, and conflict resolution techniques. Strategic Management Journal, 15(2), 135-152.

Möller, K., Windolph, M., \& Isbruch, F. (2011). The effect of relational factors on open-book accounting and inter-organizational cost management in buyersupplier partnerships. Journal of Purchasing and Supply Management, 17(2), 121-131.

Montiel, I., Husted, B. W., \& Christmann, P. (2012). Using private management standard certification to reduce information asymmetries in corrupt environments. Strategic Management Journal, 33(9), 1103-1113. 
Mouritsen, J., Hansen, A., \& Hansen, C. Ø. (2001). Inter-organizational controls and organizational competencies: episodes around target cost management/functional analysis and open book accounting. Management Accounting Research, 12(2), 221-244.

Mouritsen, J., \& Thrane, S. (2006). Accounting, network complementarities and the development of inter-organisational relations. Accounting, Organizations and Society, 31(3), 241-275.

Munday, M. (1992). Accounting cost data disclosure and buyer-supplier partnerships - a research note. Management Accounting Research, 3(3), 245250.

Noordewier, T. G., John, G., \& Nevin, J. R. (1990). Performance outcomes of purchasing arrangements in industrial buyer-vendor relationships. Journal of Marketing, 80-93.

Oh, J., \& Rhee, S.-K. (2010). Influences of supplier capabilities and collaboration in new car development on competitive advantage of carmakers. Management Decision, 48(5), 756-774.

Patnayakuni, R., Rai, A., \& Seth, N. (2006). Relational antecedents of information flow integration for supply chain coordination. Journal of Management Information Systems, 23(1), 13-49.

Porter, M. E. (1985). Competitive advantage: creating and sustaining superior performance. New york.

Prahalad, C. K., \& Hamel, G. (2006). The core competence of the corporation: Springer.

Ramos, M. (2004). Interaction between management accounting and supply chain management. Supply Chain Management: An International Journal, 9(2), 134138.

Roberts, H., Westin, O., Suomala, P., Lahikainen, T., Lyly-Yrjänäinen, J., \& Paranko, J. (2010). Open book accounting in practice-exploring the faces of openness. Qualitative Research in Accounting \& Management, 7(1), 71-96.

Romano, P., \& Formentini, M. (2012). Designing and implementing open book accounting in buyer-supplier dyads: A framework for supplier selection and motivation. International Journal of Production Economics, 137(1), 68-83.

Roodhooft, F., \& Warlop, L. (1999). On the role of sunk costs and asset specificity in outsourcing decisions: a research note. Accounting, Organizations and Society, 24(4), 363-369.

Seal, W., Berry, A., \& Cullen, J. (2004). Disembedding the supply chain: institutionalized reflexivity and inter-firm accounting. Accounting, Organizations and Society, 29(1), 73-92.

Seal, W., Cullen, J., Dunlop, A., Berry, T., \& Ahmed, M. (1999). Enacting a European supply chain: a case study on the role of management accounting. Management Accounting Research, 10(3), 303-322.

Seuring, S. (2002). Supply chain costing-a conceptual framework. Cost Management in Supply Chains, 15-30.

Shank, J. K. (1989). Strategic cost management: new wine, or just new bottles. Journal of Management Accounting Research, 1(1), 47-65. 
Singh, R., Seshadri, D., Kumra, R., Agndal, H., \& Nilsson, U. (2012). Open book practices in buyer-supplier relationships in India. Journal of Business \& Industrial Marketing, 27(3), 196-210.

Slagmulder, R. (2002). Managing costs across the supply chain Cost Management in Supply Chains (pp. 75-88): Springer.

Sohn, S.-K., Shin, I.-H., \& Park, S. (2014). Implementation of interorganizational cost management and its infrastructure: the case of a Korean 'Chaebol'firm. Asia Pacific Business Review, 21(2), 228-250.

Surowiec, A. (2013). Costing methods for supply chain management. Paper presented at the Annual International Interdisciplinary Conference, AIIC

Tomkins, C. (2001). Interdependencies, trust and information in relationships, alliances and networks. Accounting, Organizations and Society, 26(2), 161191.

Tsamenyi, M., Cullen, J., Meira, J., Kartalis, N. D., Tsamenyi, M., \& Cullen, J. (2010). Management controls and inter-firm relationships: a review. Journal of Accounting \& Organizational Change, 6(1), 149-169.

Uddin, M. (2013). Techniques of interorganizational cost management: A review essay. Journal of Statistics and Management Systems, 16(1), 89-108.

Uddin, M., \& Hassan, M. R. (2011). Conceptual Framework of Interorganizational Cost Management: a Critical Analysis. ASA University Review, 5(2), 299-312.

Van der Meer-Kooistra, J., \& Vosselman, E. G. (2000). Management control of interfirm transactional relationships: the case of industrial renovation and maintenance. Accounting, Organizations and Society, 25(1), 51-77.

Wagner, S. M. (2008). Cost management practices for supply chain management: an exploratory analysis. International Journal of Services and Operations Management, 4(3), 296-320.

Widener, S. K., \& Selto, F. H. (1999). Management control systems and boundaries of the firm: why do firms outsource internal auditing activities? Journal of Management Accounting Research, 11, 45.

Williamson, O. E. (1985). The economic intstitutions of capitalism: Free Press: New York.

Windolph, M., \& Möller, K. (2012). Open-book accounting: Reason for failure of inter-firm cooperation? Management Accounting Research, 23(1), 47-60.

Xu, L., \& Beamon, B. M. (2006). Supply chain coordination and cooperation mechanisms: an attribute-based approach. Journal of Supply Chain Management, 42(1), 4-12.

Yan, T., \& Dooley, K. J. (2013). Communication intensity, goal congruence, and uncertainty in buyer-supplier new product development. Journal of Operations Management, 31(7), 523-542.

Yeung, A. C. (2008). Strategic supply management, quality initiatives, and organizational performance. Journal of Operations Management, 26(4), 490502.

Yigitbasioglu, O. M. (2010). Information sharing with key suppliers: a transaction cost theory perspective. International Journal of Physical Distribution \& Logistics Management, 40(7), 550-578. 
Yu, S.-H., \& Chen, M.-Y. (2013). Performance impacts of Inter-organizational cooperation: a transaction cost perspective. The Service Industries Journal, 33, 1223-1241.

Zhou, H., \& Benton, W. (2007). Supply chain practice and information sharing. Journal of Operations Management, 25(6), 1348-1365. 